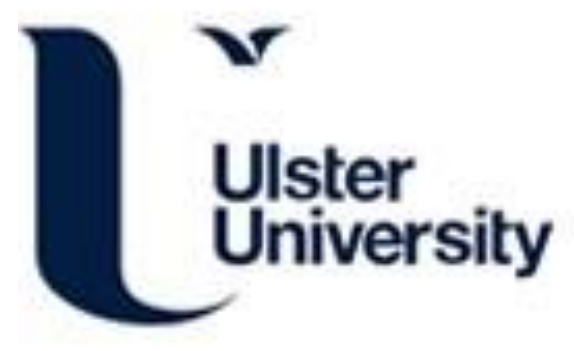

\title{
"Comparison of Ethical Issues Experienced during Palliative Care Provision in Nursing Homes in the UK and Canada: Findings from a Cross-sectional Survey"
}

Muldrew, D., Kaasalainen, S., McLaughlin, D., \& Brazil, K. (2019). "Comparison of Ethical Issues Experienced during Palliative Care Provision in Nursing Homes in the UK and Canada: Findings from a Cross-sectional Survey". Palliative Medicine. https://doi.org/10.1177/0269216319844405

Link to publication record in Ulster University Research Portal

Published in:

Palliative Medicine

Publication Status:

Published (in print/issue): 21/05/2019

DOI:

https://doi.org/10.1177/0269216319844405

\section{Document Version}

Author Accepted version

\section{General rights}

Copyright for the publications made accessible via Ulster University's Research Portal is retained by the author(s) and / or other copyright owners and it is a condition of accessing these publications that users recognise and abide by the legal requirements associated with these rights.

\section{Take down policy}

The Research Portal is Ulster University's institutional repository that provides access to Ulster's research outputs. Every effort has been made to ensure that content in the Research Portal does not infringe any person's rights, or applicable UK laws. If you discover content in the Research Portal that you believe breaches copyright or violates any law, please contact pure-support@ulster.ac.uk. 

Findings from a Cross-sectional Survey

Ulster

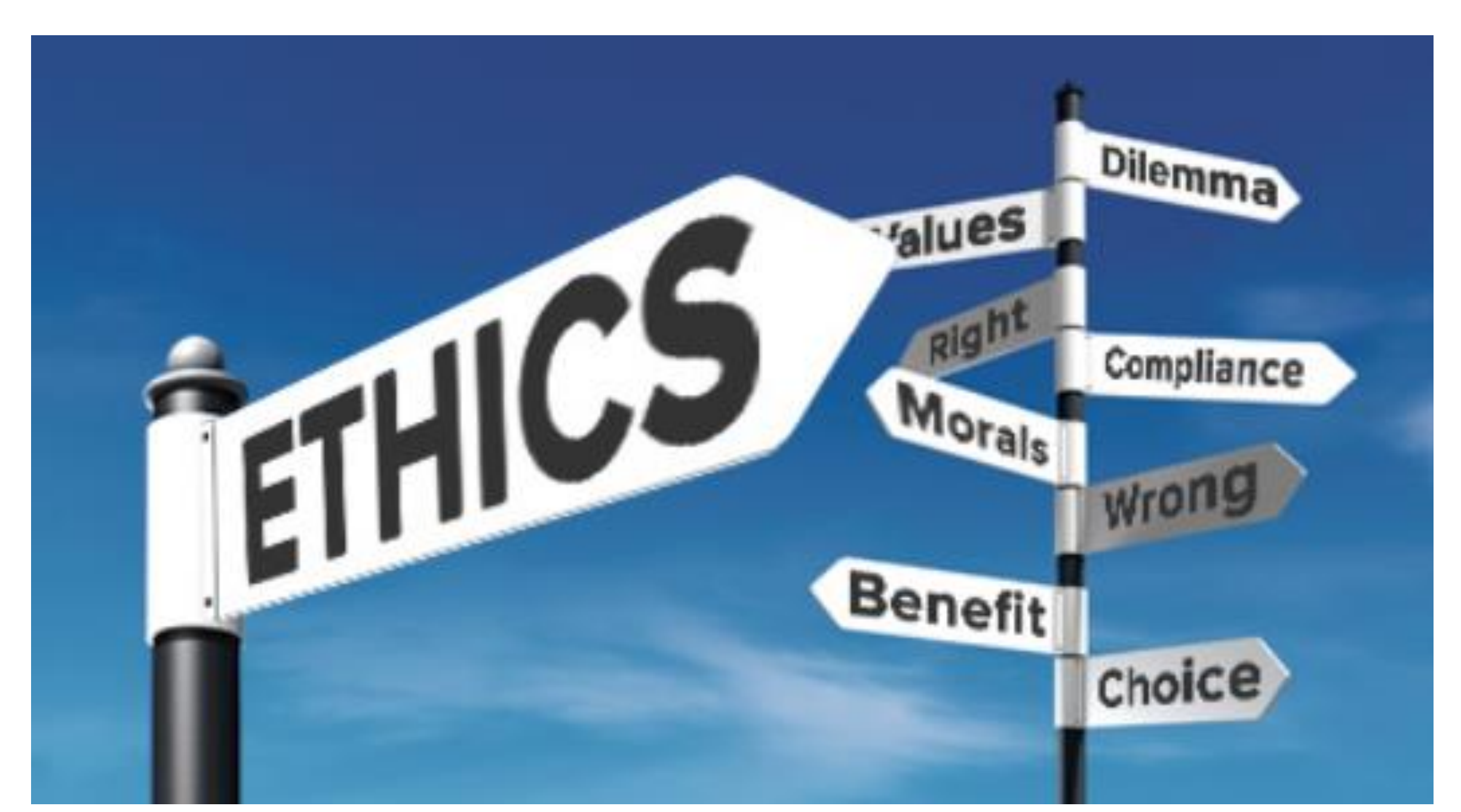

\section{Methods}

Cross-sectional survey

Sample

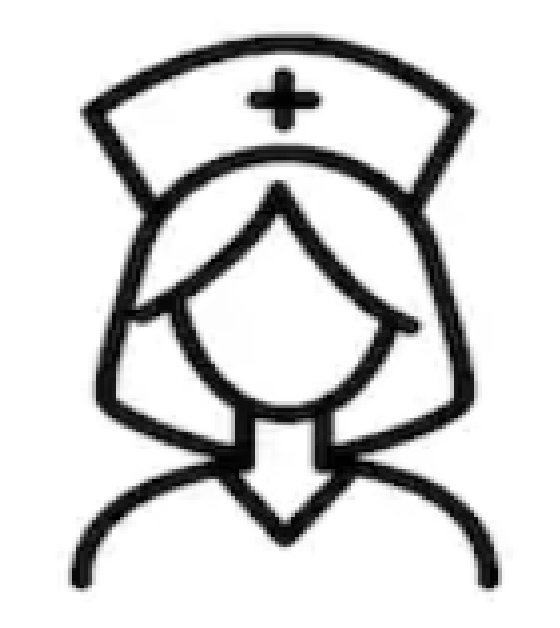

123

NURSES

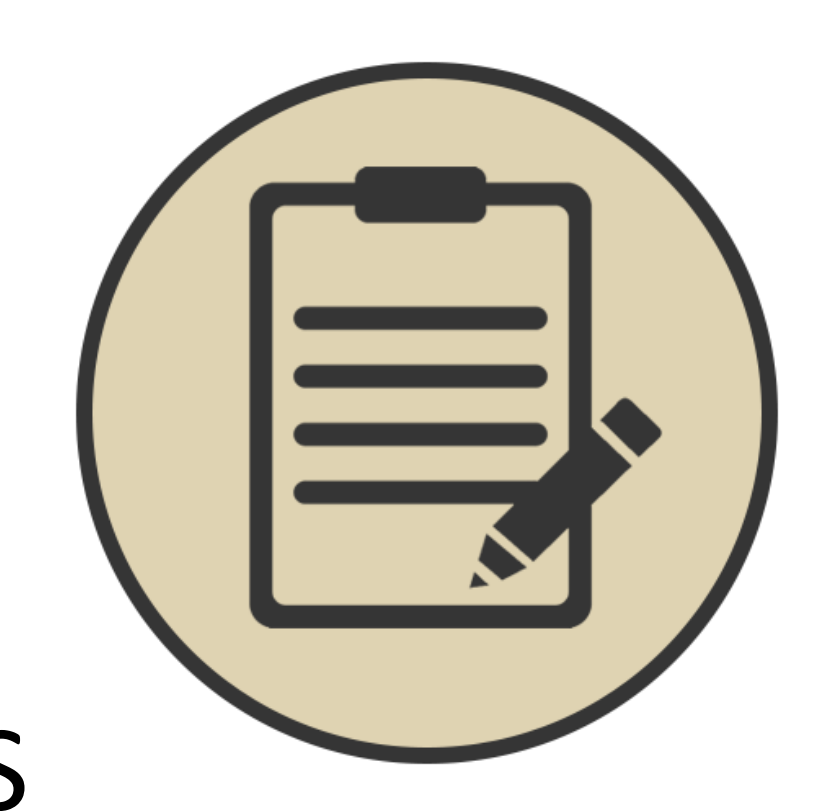

Setting: 21 Nursing Homes
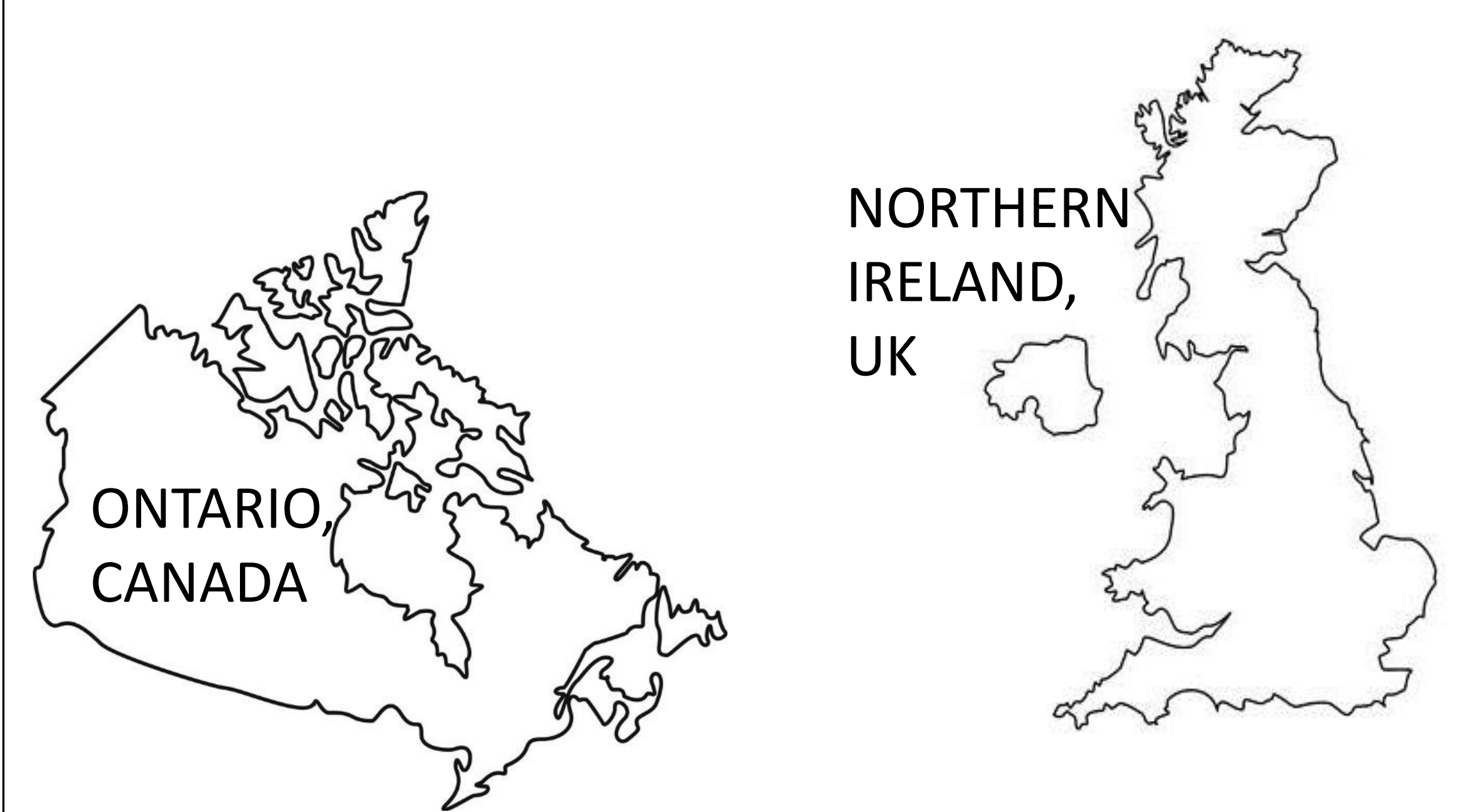

Recruitment: Two days for site visits were agreed by the nursing home managers. All nurses working that day received the "Ethical issues in Palliative Care for Nursing Homes" survey instrument.

The Instrument: The EPiCNH consists of 26 items, scored on two subscales; Frequency and Distress (Likert type scale $0-4$ ).

Analysis: Descriptive \& inferential statistics.

Approval from QUB Nursing \& Midwifery's Research Ethics Committee and the Hamilton

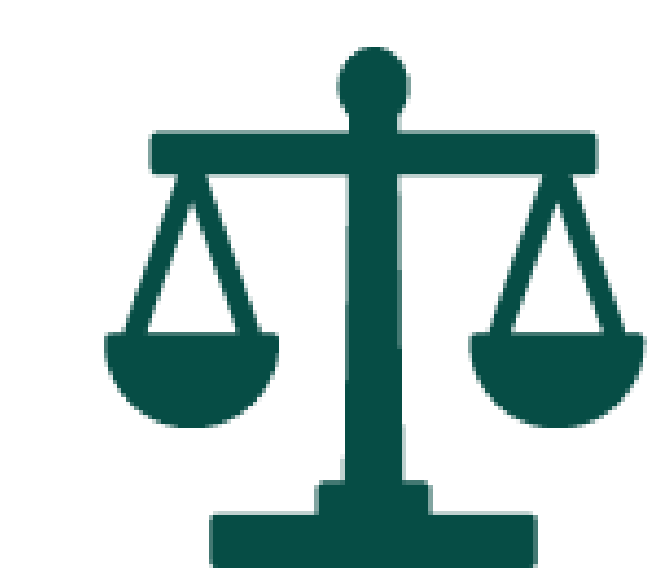

Integrated Research Ethics Board.

\section{Introduction}

Increased dependency on nursing homes to provide palliative care to an ageing population with complex care needs may lead to an increase in ethical issues, which may in turn lead to burnout and moral distress for staff.

Aim: To identify the type of ethical issues and level of associated distress experienced by nurses providing palliative care in nursing homes in the UK and Canada.

\section{Results}

Top 5 most frequent ethical issues

Item

5 I have to care for residents only accepting small amounts or refusing food and fluids near the end of life

6 I have made a decision in the resident's best interest to prevent them coming to harm or unnecessary risk

$\begin{array}{lrr}14 \text { I witness distress from } & 2.33 & 2.89(.93) \\ \text { family or care partners } & (.93) & \\ 24 \text { I am involved in non-direct } & 2.01 & 2.21 \\ \text { care activities which reduce } & (1.4) & (1.18)\end{array}$
time spent with the residents

7 I witness how poor staff
communication results in 1.84
diminished quality of care to
residents

\begin{tabular}{|c|c|c|}
\hline \multicolumn{3}{|c|}{ Top 5 most distressing ethical issues } \\
\hline \multirow[t]{2}{*}{ Item } & UK & Canada \\
\hline & $\begin{array}{l}\text { Mean } \\
\text { (SD) }\end{array}$ & Mean (SD) \\
\hline $\begin{array}{l}7 \text { I witness how poor staff } \\
\text { communication results in } \\
\text { diminished quality of care to } \\
\text { residents }\end{array}$ & $\begin{array}{l}2.47 \\
(1.30)\end{array}$ & $\begin{array}{l}2.96 \\
(.97)\end{array}$ \\
\hline $\begin{array}{l}8 \text { I have observed professional } \\
\text { incompetence due to } \\
\text { insufficient staff training for } \\
\text { providing nursing care }\end{array}$ & $\begin{array}{l}2.42 \\
(1.37)\end{array}$ & $\begin{array}{l}2.81 \\
(1.21)\end{array}$ \\
\hline $\begin{array}{l}20 \text { I don't have enough time to } \\
\text { provide the resident with the } \\
\text { care she/he needs }\end{array}$ & $\begin{array}{l}2.25 \\
(1.46)\end{array}$ & $\begin{array}{l}2.71 \\
(1.35)\end{array}$ \\
\hline $\begin{array}{l}24 \text { I am involved in non-direct } \\
\text { care activities which reduce } \\
\text { time spent with the residents }\end{array}$ & & $\begin{array}{l}2.16 \\
(1.12)\end{array}$ \\
\hline $\begin{array}{l}15 \text { I have to follow the family's } \\
\text { or care partner's wishes for the } \\
\text { resident's care when I do not } \\
\text { agree with them }\end{array}$ & & $\begin{array}{l}2.43 \\
(1.06)\end{array}$ \\
\hline
\end{tabular}

\section{Discussion}

- Nursing homes should be aware of the ethical struggles faced by their staff.

- The findings encourage a greater level of discussion within nursing homes regarding the everyday ethical issues faced and offer suggestions for how to overcome them.

Training on ethical debate has been acknowledged as a global recommendation for improving palliative care.

References
"An ethical issue occurs where there is doubt, uncertainty or disagreement about what is morally good or right" $(1)$

Palliative care refers to "the active holistic care of patients with advanced progressive illness"(2)
1. Hem MH, Molewijk B, Gjerberg E, et al. The significance of ethics reflection groups in mental health care: a focus group study among health care professionals. BMC Med Ethics 2018;19:54. doi:10.1186/s12910-018-0297-y 2. National Council for Palliative Care. Palliative Care Explained. https://www.ncpc.org.uk/palliative-care-explained (accessed 10 Oct 2018).

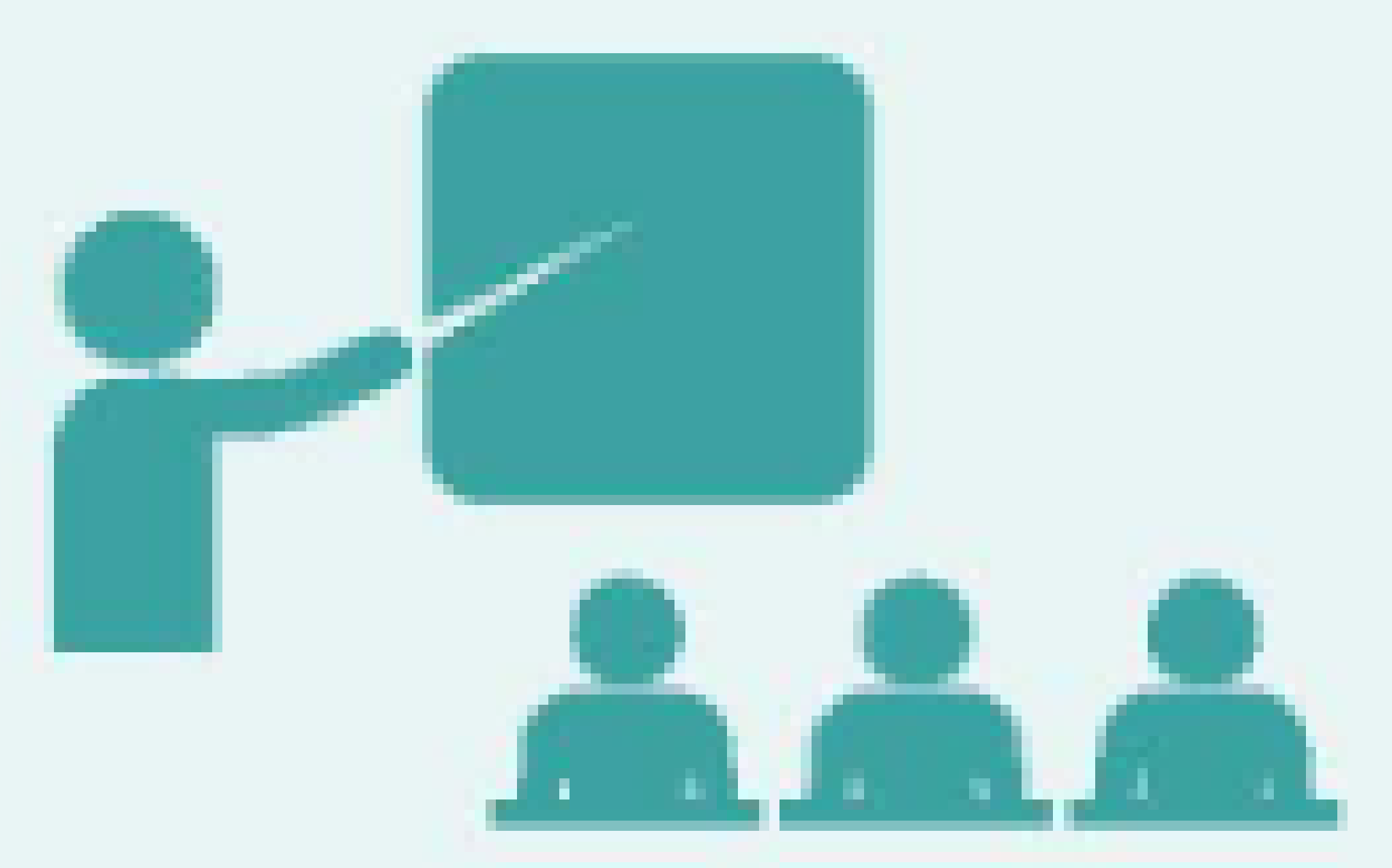

you would like more information, please contact Deborah Muldrew: d.Muldrew@ulster.ac.uk Poster author will be present: Poster Presentation Set 2 on 24.05 .2019

I have no potential conflict of interest to report 